\title{
Dynamics of the Degradation of Acetyl-CoA Carboxylase Herbicides in Vegetables
}

\author{
Miroslav Jursík $^{1, *\left(\mathbb{C}, \text { Kateřina Hamouzová }^{1}(\mathbb{D} \text { and Jana Hajšlová }\right.}{ }^{2}$ \\ 1 Faculty of Agrobiology, Food and Natural Resources, Czech University of Life Sciences Prague, \\ 16500 Prague, Czech Republic; hamouzova@af.czu.cz \\ 2 Department of Food Analysis and Nutrition, University of Chemistry and Technology Prague, \\ 16628 Prague, Czech Republic; jana.hajslova@vscht.cz \\ * Correspondence: jursik@af.czu.cz
}

Citation: Jursík, M.; Hamouzová, K.; Hajšlová, J. Dynamics of the Degradation of Acetyl-CoA Carboxylase Herbicides in Vegetables. Foods 2021, 10, 405. https://doi.org/ $10.3390 /$ foods 10020405

\section{Academic Editor:}

Roberto Romero-González

Received: 11 January 2021

Accepted: 8 February 2021

Published: 12 February 2021

Publisher's Note: MDPI stays neutral with regard to jurisdictional claims in published maps and institutional affiliations.

Copyright: (c) 2021 by the authors. Licensee MDPI, Basel, Switzerland. This article is an open access article distributed under the terms and conditions of the Creative Commons Attribution (CC BY) license (https:/ / creativecommons.org/licenses/by/ $4.0 /)$.

\begin{abstract}
Background: Aryloxyphenoxy-propionates and cyclohexanediones are herbicides most widely used in dicot crops worldwide. The main objective of the study was to determine the dynamics of herbicide residues in carrot, lettuce, cauliflower, and onion in order to suggest a low level of residues in harvested vegetables. (2) Methods: Small plot field trials were carried out in four vegetables in the Czech Republic. The samples of vegetables were collected continuously during the growing season. Multiresidue methods for the determination of herbicide residues by LC-MS/MS were used. Non-linear models of degradation of individual herbicides in vegetables were calculated using the exponential decay formula. Action GAP pre-harvest intervals for the $25 \%$ and $50 \%$ maximum residue limit (MRL) and $10 \mu \mathrm{g} \mathrm{kg}^{-1}$ limit (baby food) were established for all tested herbicides. (3) Results: The degradation dynamics of fluazifop in carrot, onion, and cauliflower was significantly slower compared to quizalofop and haloxyfop. The highest amount $\left(2796 \mu \mathrm{g} \mathrm{kg}^{-1}\right)$ of fluazifop residues was detected in cauliflower 11 days after application. No residue of propaquizafop and cycloxydim was detected in any vegetable samples. (4) Conclusions: Aryloxyphenoxy-propionate herbicide (except propaquizafop) could contaminate vegetables easily, especially vegetables with a short growing season. Vegetables treated with fluazifop are not suitable for baby food. Lettuce and cauliflower treated by quizalofop are not suitable for baby food, but in onion and carrot, quizalofop could be used. Propaquizafop and cycloxydim are prospective herbicides for non-residual (baby food) vegetable production.
\end{abstract}

Keywords: herbicide residues; non-residual production; low-residual production; pesticide degradation in vegetables

\section{Introduction}

Aryloxyphenoxy-propionates (FOPs) and cyclohexanediones (DIMs) are the most commonly used leaf graminicides (herbicides against grass weeds) in dicotyledonous (dicot) crops [1-3]. Herbicides of both chemical groups block the conversion of acetyl-CoA to malonyl-CoA by inhibiting the activity of the enzyme acetyl-CoA carboxylase (ACCase). This inhibition of fatty acid synthesis blocks the production of phospholipids used in building new cell membranes required for cell growth [4]. Dicot plants are naturally tolerant of these herbicides because of an insensitive ACCase, but tank-mix combinations with other herbicides could cause great damage to treated crops, especially under unsuitable weather conditions [5].

FOPs are formulated and applied as an ester of their acids. Emulsifiable concentrate is a common formulation for these herbicides. After application, esters are rapidly converted to acids by carboxyesterase activity. Acid forms are readily translocated to the meristematic tissues through the phloem. This process inhibits the growth of young developing leaves of susceptible grass weeds [6]. Necroses of the growing points are visible two weeks after application depending on the temperature. 
FOPs are applied post-emergently because they are taken up by the leaves of plant, but some herbicide will also fall to the soil [7]. The soil fate of FOPs will depend on soil $\mathrm{pH}$, with slower degradation in alkaline soils [8]. There is also a concern of water being contamination with these herbicides, as documented in Greek surface waters with quizalofop [9] and Brazilian rivers with haloxyfop [10]. On the other hand, Mantzos et al. [11] showed minimal risk of the contamination of the soil and adjacent water by quizalofop. These herbicides had transient, harmful effects on most of the soil's microbiological parameters [12].

Conventional farming practices include the use of pesticides within an integrated pest management program for crop protection against diseases, pests, and weeds. However, pesticides are potentially toxic to humans and can have both acute and chronic health effects, depending on the quantity and ways in which a person is exposed [13]. For this reason, it is necessary to model pesticide distribution in harvested crops [14]. Maximum residue limits (MRLs) for pesticides in crops were established by the European Union in a regulation of the European Commission [15] as the highest level of pesticide residues that are tolerated in food. Low-residual production is a designation for agricultural production where residues of used pesticides in harvested products are below the limit for a predetermined action threshold, for example $25 \%$ MRL or 50\% MRL $[13,16]$. Furthermore, non-residue production is a classification for products with pesticide residues below the limit of $10 \mu \mathrm{g} \mathrm{kg}^{-1}$. This limit is currently used worldwide for baby foods [17]. Some FOPs (diclofop, haloxyfop, quizalofop) contain chlorine, and these herbicides could metabolize to chlorate, especially in carrots and potatoes. These would be unacceptable for baby food products [18].

Accumulation of pesticide residues in vegetables is less frequent than in fruits [19]. Within vegetables, pesticide residues are most widely detected in pepper and cucumber, while samples of lettuce, cauliflower, and carrots seldom contained pesticide residues [20,21]. This is not to say that residues are never detected in these vegetables. Elgueta et al. [22] and Skovgaard et al. [23] detected pesticide residues in $50 \%$ of lettuce samples with $16-20 \%$ of samples above the MRL. Santareli et al. [24] also detected many lettuce samples over the MRL in Italy. Even organically managed vegetables could be occasionally contaminated by pesticide residues, especially in countries where the control of pesticide use is less strict. For example, in Brazil, a large number of organic carrot samples contain pesticide residues [25].

Most of above-mentioned studies detected insecticides or fungicides in vegetables, but few studies have monitored the contamination of vegetables by herbicides. For example, Sing et al. [26] monitored pre-emergent herbicides in carrots, but no residue was detected. Similar results published by Saritha et al. [27] did not detect any residues of metribuzin in tomato. Khan et al. [28] detected residues of linuron in onion, carrot, and lettuce. There are a few cases where pendimethalin was detected in vegetables $[29,30]$, especially in vegetables with a short growing season like lettuce [31] or kohlrabi [32]. Risk of contamination by FOP residues is quite high because late post-emergence application is on the label, but to our knowledge, no study has focused on the degradation dynamics of FOPs yet.

The main objective of this study was to determine the degradation dynamics of herbicide residues in carrot, lettuce, cauliflower, and onion to provide suggestions for low-residue production of harvested vegetables. The specific objectives of this work were (1) to quantify the concentration of herbicide residues in tested vegetables, (2) to develop recommendations for herbicide weed control for low-residual and non-residual vegetable production, and (3) to recommend the safest leaf graminicide for each tested vegetable.

\section{Materials and Methods}

Small plot field trials were carried out in carrot (variety Grivola), onion (variety Wellington), lettuce (variety Elenas), and cauliflower (variety Chamborg) in a field of the University of Life Sciences, Prague, the Czech Republic (300 m a.s.l., 50 ${ }^{\circ} 7^{\prime} \mathrm{N}, 14^{\circ} 22^{\prime} \mathrm{E}$ ) in 2012-2016. The region has a temperate climate with an annual mean air temperature of about $9{ }^{\circ} \mathrm{C}$ and a mean annual precipitation of about $500 \mathrm{~mm}$. None of the tested herbicides were used in previous crops (potatoes). Each vegetable was grown in a separate growing area 
with specific agrotechnological requirements (soil preparation, fertilization, and irrigation). Common agricultural practices of the European and Mediterranean Plant Protection Organization were used. Experimental plots were arranged in randomized blocks. Plot size was $16 \mathrm{~m}^{2}(2 \mathrm{~m} \times 8 \mathrm{~m})$ for each vegetable. Crop density, row spacing, and planting/sowing times are given in Table 1.

Table 1. Crop and plot arrangements.

\begin{tabular}{|c|c|c|c|c|c|c|c|}
\hline \multirow{2}{*}{ Vegetable } & \multirow{2}{*}{$\begin{array}{l}\text { Crop Density } \\
\text { (Plant } \mathrm{m}^{-2} \text { ) }\end{array}$} & \multirow{2}{*}{$\begin{array}{c}\text { Inter-Row } \\
\text { Spacing (m) }\end{array}$} & \multicolumn{5}{|c|}{ Date of Planting/Sowing } \\
\hline & & & 2012 & 2013 & 2014 & 2015 & 2016 \\
\hline carrot & 90 & 0.5 & 25.3 & 20.4 & 31.3 & 21.4 & 28.4 \\
\hline onion & 70 & 0.3 & 29.3 & 15.4 & 12.3 & 30.3 & - \\
\hline lettuce & 10 & 0.3 & 28.3 & 9.4 & 27.3 & - & - \\
\hline cauliflower & 4 & 0.5 & 9.5 & 6.5 & 5.5 & - & - \\
\hline
\end{tabular}

The samples of vegetable (roots of carrot, bulbs of onion, leaves of lettuce and florets of cauliflower) were collected continuously during the growing season from the central part of each plot. There was a two-week interval between the first and second sampling and between the second and third sampling. A minimum of four plants was collected from one plot during each sampling term. The samples were stored at $-20{ }^{\circ} \mathrm{C}$ until the extraction procedure.

All tested herbicides (Table 2) were formulated as emulsifiable concentrates. A smallplot sprayer, fitted with a Lurmark 015F110 nozzle, was used to apply the herbicides. The application pressure was $0.25 \mathrm{MPa}$, and the water volume applied was $300 \mathrm{~L} / \mathrm{ha}$. The maximum registered rates of all tested herbicides were used. Herbicides were applied post-emergently in two terms (Table 3).

Table 2. Description of tested herbicides.

\begin{tabular}{ccccc}
\hline $\begin{array}{c}\text { Active } \\
\text { Ingredient (ai) }\end{array}$ & Trade Name & $\begin{array}{c}\text { Concentration } \\
\left.\text { of ai } \mathbf{~ ( g ~ L ~}^{-\mathbf{1}}\right)\end{array}$ & $\begin{array}{c}\text { Application } \\
\text { Rate }\left(\mathbf{g ~ h a}^{-\mathbf{1}} \mathbf{~ a i )}\right.\end{array}$ & Manufacturer \\
\hline cycloxydim & Stratos Ultra & 100 & 200 & BASF \\
fluazifop & Fusilade Forte & 150 & 300 & Syngenta \\
haloxyfop & Gallant Super & 104 & 104 & Corteva \\
propaquizafop & Agil & 100 & 150 & ADAMA \\
quizalofop & Targa Super & 100 & 250 & Chemtura \\
\hline
\end{tabular}

Table 3. Term of herbicide application in experimental years.

\begin{tabular}{ccccccc}
\hline \multirow{2}{*}{ Vegetable } & Growth & \multicolumn{5}{c}{ Date of Herbicide Application } \\
\cline { 3 - 7 } & Stage & $\mathbf{2 0 1 2}$ & $\mathbf{2 0 1 3}$ & $\mathbf{2 0 1 4}$ & $\mathbf{2 0 1 5}$ & $\mathbf{2 0 1 6}$ \\
\cline { 3 - 7 } carrot & $5 \mathrm{TL}{ }^{1}$ & 27.6 & 24.6 & 16.6 & 17.6 & 16.6 \\
& $7 \mathrm{TL}$ & 9.7 & 7.7 & 23.6 & 30.6 & 28.6 \\
& $9 \mathrm{TL}$ & - & 15.7 & 7.7 & - & - \\
\hline \multirow{2}{*}{ onion } & $6 \mathrm{~L}^{2}$ & 11.6 & 7.7 & 11.6 & 17.6. & - \\
& $9 \mathrm{~L}$ & 27.6 & 22.7 & 7.7 & 13.7. & - \\
\hline \multirow{2}{*}{ lettuce } & $4 \mathrm{WAP}$ & 15.5 & 13.5 & 23.5 & - & - \\
& $6 \mathrm{WAP}$ & 25.5 & 29.5 & 3.6 & - & - \\
\hline \multirow{2}{*}{ cauliflower } & $6 \mathrm{WAP}$ & 19.6 & 24.6 & 23.6 & - & - \\
& $8 \mathrm{WAP}$ & 27.6 & 7.7 & 7.7 & - & - \\
\hline
\end{tabular}

${ }^{1}$ true leaves, ${ }^{2}$ leaves, ${ }^{3}$ weeks after planting.

Analyses of pesticide residues were performed by the testing laboratory of the University of Chemistry and Technology using the LC-MS/MS method accredited according to 
the EN ISO/IEC 17025 standard [33]. The analytical method used in this study is based on EN standards [34].

In brief, the following steps were performed: (i) alkaline hydrolysis $(10 \mathrm{~mL}$ of acetonitrile and $2 \mathrm{~mL}$ of $5 \mathrm{M} \mathrm{NaOH}$ added to $10 \mathrm{~g}$ of homogenized sample, shaking $2 \mathrm{~h}$ at $40{ }^{\circ} \mathrm{C}$ ); (ii) acidification ( $2 \mathrm{~mL}$ of $2.5 \mathrm{M} \mathrm{H}_{2} \mathrm{SO}_{4}$ ) and addition of $100 \mu \mathrm{L}$ formic acid); (iii) QuEChERS like extraction (addition of $4 \mathrm{~g} \mathrm{MgSO}_{4}$ and $1 \mathrm{~g}$ of $\mathrm{NaCl}$; and internal standard, triphenylphosphate, then, intensive shaking; centrifugation to separate acetonitrile phase for further analysis). An aliquot of the upper organic layer was transferred to a vial for LC-MS/MS. An Acquity UPLC HSS T3 analytical column (100 mm $\times 2.1 \mathrm{~mm}$, $1.8 \mu \mathrm{m}$ particle size, Waters, USA) and mobile phases consisting of (A) water with $5 \mathrm{mM}$ ammonium formate $/ 0.1 \%(v / v)$ formic acid and $(\mathrm{B})$ methanol were used for ultra-high performance liquid chromatography (U-HPLC) in extract separation. A triple quadrupole mass spectrometer (Xevo TQ-S, Waters, Milford, MA, USA) with electrospray ionization in a positive ion mode (ESI+) was used for the final identification and quantification of herbicide residues (Table 4). The method used for residues analysis was fully validated in line with the requirements stated in the European Commission's guidance document SANTE/12682/2019 [35]. Limits of quantification together with maximum residue limits (MRLs) established by Regulation EC 396/2005, are summarized in Table 5. The extended uncertainty of measurement at $0.01 \mathrm{mg} / \mathrm{kg}$ level was $15 \%$. To avoid results bias due to matrix effects, matrix-matched calibration was used.

Table 4. Mass spectrometric detector setting.

\begin{tabular}{lcccccc}
\hline \multirow{2}{*}{ Analyte } & Quantification & Cone & Collision & Confirmation & Cone & Collision \\
\cline { 2 - 7 } & Transition $(\boldsymbol{m} / \boldsymbol{z})$ & $\mathbf{( V )}$ & $\mathbf{( V )}$ & $\begin{array}{c}\text { Transition } \\
(\boldsymbol{m} / \boldsymbol{z})\end{array}$ & $\mathbf{( V )}$ & $\mathbf{( V )}$ \\
\hline Cycloxydim & $326.3>280.2$ & 30 & 13 & $326.3>180.4$ & 30 & 25 \\
Fluazifop & $328.2>282.1$ & 35 & 20 & $328.2>91.2$ & 35 & 30 \\
Haloxyfop & $362>315.8$ & 27 & 18 & $362>91$ & 27 & 30 \\
Propaquizafop & $444.2>100.04$ & 30 & 20 & $444.2>56.2$ & 30 & 15 \\
Quizalofop & $344.46>298.83$ & 54 & 18 & $346.46>300.83$ & 54 & 18 \\
\hline
\end{tabular}

Table 5. Limits of quantification and maximum residue limit for tested herbicides and vegetables.

\begin{tabular}{ccccccccc}
\hline \multirow{2}{*}{ Herbicide } & \multicolumn{2}{c}{ Carrot } & \multicolumn{2}{c}{ Onion } & \multicolumn{2}{c}{ Lettuce } & \multicolumn{2}{c}{ Cauliflower } \\
\cline { 2 - 9 } & LOQ $^{\mathbf{1}}$ & MRL $^{2}$ & LOQ & MRL & LOQ & MRL & LOQ & MRL \\
\cline { 2 - 9 } & \multicolumn{7}{c}{$\boldsymbol{\mu g ~ \mathbf { ~ k g } ^ { - 1 }}$} \\
\hline cycloxydim & 2 & 5000 & - & 3000 & 2 & 1500 & 2 & 5000 \\
fluazifop & 2 & 400 & 1 & 300 & 1 & 20 & 1 & 10 \\
haloxyfop & 2 & 90 & 2 & 200 & - & 10 & - & 10 \\
propaquizafop & 2 & 200 & 2 & 40 & 2 & 400 & 2 & 200 \\
quizalofop & 2 & 200 & 1 & 40 & 1 & 400 & 1 & 200 \\
\hline
\end{tabular}

${ }^{1}$ limit of quantification, ${ }^{2}$ maximum residue limit.

The generated data was processed using MassLynx software version 4.1 (Waters Corporation, Milford, USA). External quality control was ensured by regular participation in proficiency tests of the European Commission's Proficiency Testing Program.

The obtained data were processed in $R$ project version 3.6.1 (R Core Team, 2019) and subjected to the comparison analysis ( $t$-test) to reflect the differences in experimental years. Non-linear models of degradation of individual herbicides in crops were calculated using the exponential decay formula in drc package using the following equation:

$$
\mathrm{y}=\mathrm{a}(\exp (-\mathrm{x} / \mathrm{b}))
$$


where y was the amount of active ingredient $\left(\mu \mathrm{g} \mathrm{kg}^{-1}\right)$, $\mathrm{x}$ was number of days after herbicide application, parameter $b>0$ determined the steepness of decay, and a was the upper limit. Goodness of fit was assessed by F-test. All tests were performed using a significance level of 0.05 . Parameters of models and the analytical results are shown in Table 6.

Table 6. Parameters of the exponential decay model and analytical results.

\begin{tabular}{cccccccc}
\hline \multirow{2}{*}{ Vegetable } & $\begin{array}{c}\text { Active } \\
\text { Ingredient }\end{array}$ & \multicolumn{7}{c}{ Parameter } \\
\cline { 3 - 8 } & & $\mathbf{a}^{\mathbf{1}}$ & $\mathbf{S E}^{\mathbf{2}}$ & $\mathbf{b}^{\mathbf{1}}$ & $\mathbf{S E}$ & F-Test $^{\mathbf{3}}$ & $\boldsymbol{p}$-Value \\
\hline \multirow{3}{*}{ carrot } & fluazifop & 804.09 & 121.91 & 18.82 & 3.39 & 0.55 & 0.91 \\
& quizalofop & 78.56 & 13.19 & 32.89 & 7.85 & 1.67 & 0.16 \\
& haloxyfop & 153.15 & 19.57 & 17.66 & 2.43 & 0.94 & 0.64 \\
\hline \multirow{3}{*}{ onion } & fluazifop & 458.81 & 67.95 & 10.30 & 1.18 & 2.28 & 0.12 \\
& quizalofop & 108.76 & 25.03 & 9.24 & 1.73 & 0.40 & 0.90 \\
& haloxyfop & 81.98 & 12.08 & 18.57 & 2.94 & 7.57 & 0.13 \\
\hline \multirow{2}{*}{ lettuce } & fluazifop & 1194.64 & 617.99 & 9.45 & 3.77 & 8.97 & 0.30 \\
& quizalofop & 262.89 & 120.05 & 29.10 & 21.72 & 3.91 & 0.14 \\
\hline \multirow{2}{*}{ cauliflower } & fluazifop & 5905.47 & 800.93 & 12.4 & 1.31 & 7.77 & 0.12 \\
& quizalofop & 107.99 & 33.25 & 26.77 & 10.17 & 4.95 & 0.18 \\
\hline
\end{tabular}

${ }_{1}^{1}$ parameters of model - $a$ represents upper limit of the curve, $b$ is the steepness of the decay, ${ }^{2}$ standard error 3 significance $p=0.05$.

Action pre-harvest intervals for the 50\% MRL (APHI $\left.{ }_{50}\right), 25 \% \mathrm{MRL}\left(\mathrm{APHI}_{25}\right)$, and $10 \mu \mathrm{g} \mathrm{kg}^{-1}$ limit $\left(\mathrm{APHI}_{\mathrm{BF}}\right.$ ) were established for fluazifop and quizalofop in all four vegetables and for haloxyfop in onion and carrot. The above-mentioned equation was used to calculate the APHI (as variable $\mathrm{x}$ ). For non-residue production, a concentration of $10 \mu \mathrm{g}$ $\mathrm{kg}^{-1}$ was used. A given percentage of the MRL (50 and 25\%) was calculated for low-residue production. The calculated value of APHIs was extended by one-third depending on a confidence interval of the model for each herbicide with the aim of increasing the reliability of APHIs, i.e.,

$$
\mathrm{APHI}=\mathrm{t}+(1 / 3 \mathrm{t})
$$

The MRL parameter differs according to the active ingredient of the herbicide and the vegetable. The PHI was used when the computed APHI value extended by one-third was lower than the compulsory PHI as indicated in the list of registered products [36].

\section{Results}

\subsection{Carrot}

The degradation dynamics of fluazifop in carrot were significantly slower compared to quizalofop and haloxyfop. Relatively high differences in the degradation dynamics of fluazifop were recorded among the experimental growing season and application term, nevertheless, the differences were not statistically significant. The highest concentrations of fluazifop (above $500 \mu \mathrm{g} \mathrm{kg}^{-1}$ ) in carrot were detected in the first two weeks after application. The degradation dynamics of quizalofop and haloxyfop were similar and any analyzed samples of onion did not contain more than $150 \mathrm{\mu g} \mathrm{kg}^{-1}$ (Figure 1). For fluazifop, quizalofop, and haloxyfop, the values of $\mathrm{APHI}_{50}$ were shorter than PHI. Similarly, the values of $\mathrm{APHI}_{25}$ for quizalofop and haloxyfop ( 25 and 45 days, respectively) were shorter than PHI (45 and 56 days, respectively). In such cases, the APHI was not relevant. While modeling the quizalofop curve, the negative value appeared. It was due to low observed values in the experiment and high MRL. The longest $\mathrm{APHI}_{\mathrm{BF}}$ (110 days) was calculated for fluazifop (Table 7). Any residue of propaquizafop and cycloxydim was not detected in any sample of carrot, regardless of the application term and year of sampling. 


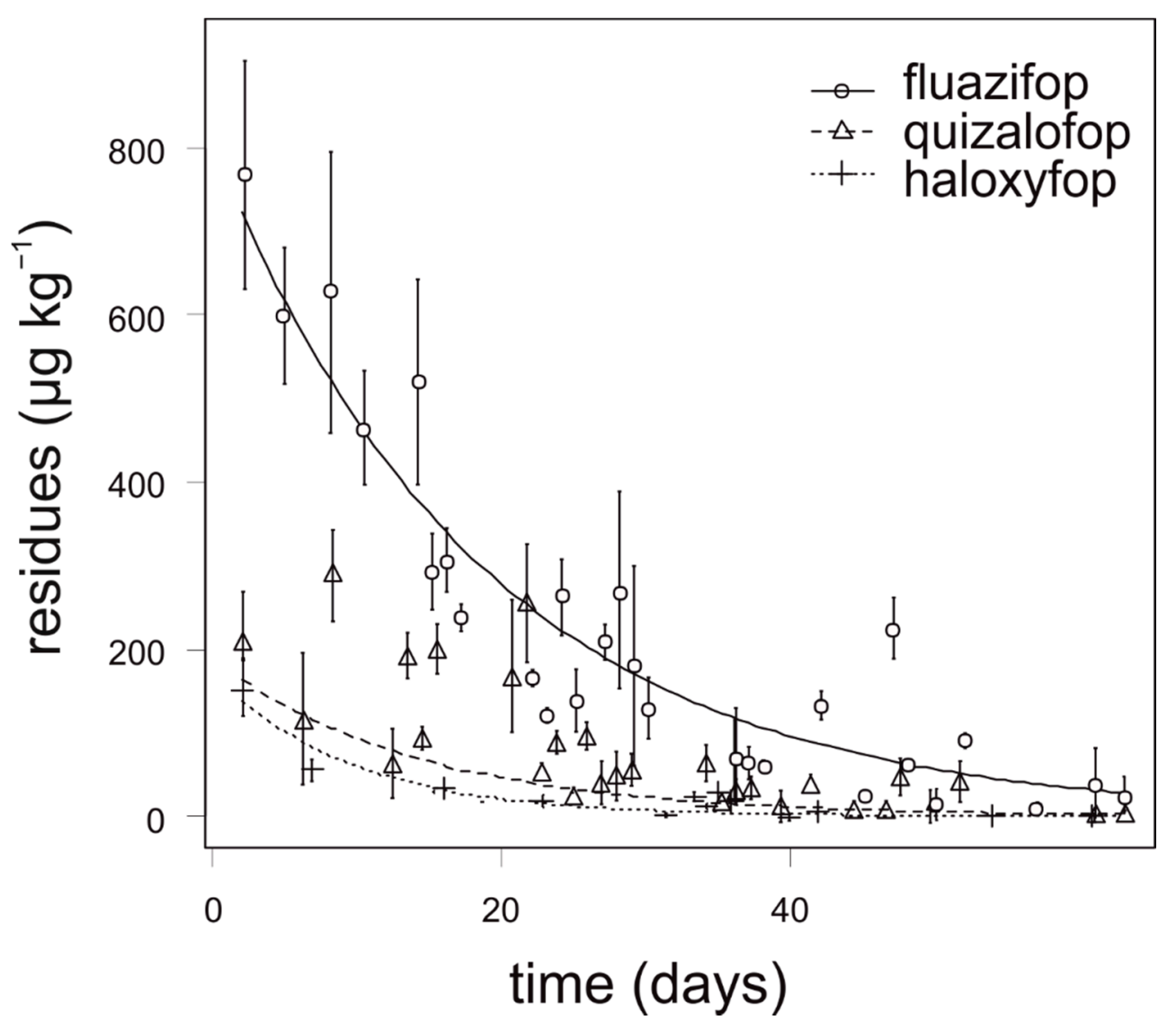

Figure 1. Degradation dynamics of fluazifop, quizalofop, and haloxyfop in carrot. Mean values with error bars representing standard error of the mean.

Table 7. Active pre-harvest interval for tested herbicides in tested vegetables for current MRL.

\begin{tabular}{|c|c|c|c|c|c|c|c|}
\hline Vegetable & $\begin{array}{c}\text { Active } \\
\text { Ingredient }\end{array}$ & $\begin{array}{c}\mathrm{MRL}^{1} \\
\left(\mu \mathrm{g} \mathrm{kg}^{-1}\right)\end{array}$ & $\begin{array}{c}\text { Model ( } \mu \mathrm{g} \\
\left.\mathrm{kg}^{-1}\right)\end{array}$ & $\begin{array}{c}\mathrm{PHI}^{2} \\
\text { (Days) }\end{array}$ & $\begin{array}{c}\mathrm{APHI}_{\mathrm{BF}}{ }^{3} \\
\text { (Days) }\end{array}$ & $\begin{array}{c}\mathrm{APHI}_{25} 4 \\
\text { (Days) }\end{array}$ & $\begin{array}{c}\mathrm{APHI}_{50}{ }^{4} \\
\text { (Days) }\end{array}$ \\
\hline \multirow{3}{*}{ carrot } & fluazifop & 400 & 13.14 & 49 & 110 & 52 & 35 \\
\hline & quizalofop & 200 & $-0.81^{5}$ & 45 & 55 & 25 & 12 \\
\hline & haloxyfop & 90 & 9.38 & 56 & 64 & 45 & 29 \\
\hline \multirow{3}{*}{ onion } & fluazifop & 300 & 4.38 & 28 & 53 & 25 & 15 \\
\hline & quizalofop & 40 & 9.24 & 42 & 29 & 29 & 21 \\
\hline & haloxyfop & 200 & $-9.29^{5}$ & 28 & 47 & 15 & 2 \\
\hline \multirow{2}{*}{ lettuce } & fluazifop & 20 & 38.64 & 42 & 60 & 69 & 60 \\
\hline & quizalofop & 400 & 5.22 & 30 & 71 & 31 & 19 \\
\hline \multirow{2}{*}{ cauliflower } & fluazifop & 10 & 79.13 & 56 & 105 & $128^{5}$ & $117^{5}$ \\
\hline & quizalofop & 200 & 2.57 & 70 & 68 & 33 & 18 \\
\hline
\end{tabular}

${ }^{1}$ maximum residue limit, ${ }^{2}$ pre-harvest interval, ${ }^{3}$ active pre-harvest interval for baby food $\left(10 \mu \mathrm{g} \mathrm{kg}{ }^{-1}\right),{ }^{4}$ active pre-harvest interval for low-residual production (25, resp. 50\% MRL, ${ }^{5}$ value is less than active pre-harvest interval for baby food $(10 \mu \mathrm{g} \mathrm{kg})$ due to low MRL,

${ }^{5}$ Due to the low observed values in experiment and high MRL value, the model results in some negative predictions for quizalofop (carrot) and haloxyfop (onion).

\subsection{Onion}

Fluazifop showed the slowest degradation in onion, especially during the first four weeks after application. The highest concentration of fluazifop $\left(235 \mu \mathrm{g} \mathrm{kg}^{-1}\right)$ in onion was detected 7 days after application. The degradation dynamics of quizalofop and haloxyfop was similar and all analyzed samples of onion contained no more than $70 \mu \mathrm{g} \mathrm{kg}-1$ (Figure 2). For quizalofop, the calculated $\mathrm{APHI}_{25}$ was equal to the $\mathrm{APHI}_{\mathrm{BF}}$ due to a low 
MRL $\left(40 \mu \mathrm{g} \mathrm{kg}^{-1}\right)$. For fluazifop and haloxyfop, the $\mathrm{APHI}_{50}$ and $\mathrm{APHI}_{25}$ were shorter than PHI. Modeled values of haloxyfop reached a negative value (Table 6); this is due to two facts. First, the MRL established by authorities is quite high and, second, the observed values did not reach such a high value. For quizalofop, the $\mathrm{APHI}_{\mathrm{BF}}$ (29 days) was shorter than PHI (42 days). In such cases, the APHI was not relevant (Table 7). Incidence of propaquizafop residue was not detected in any tested onion sample. Cycloxydim was not tested in onion.

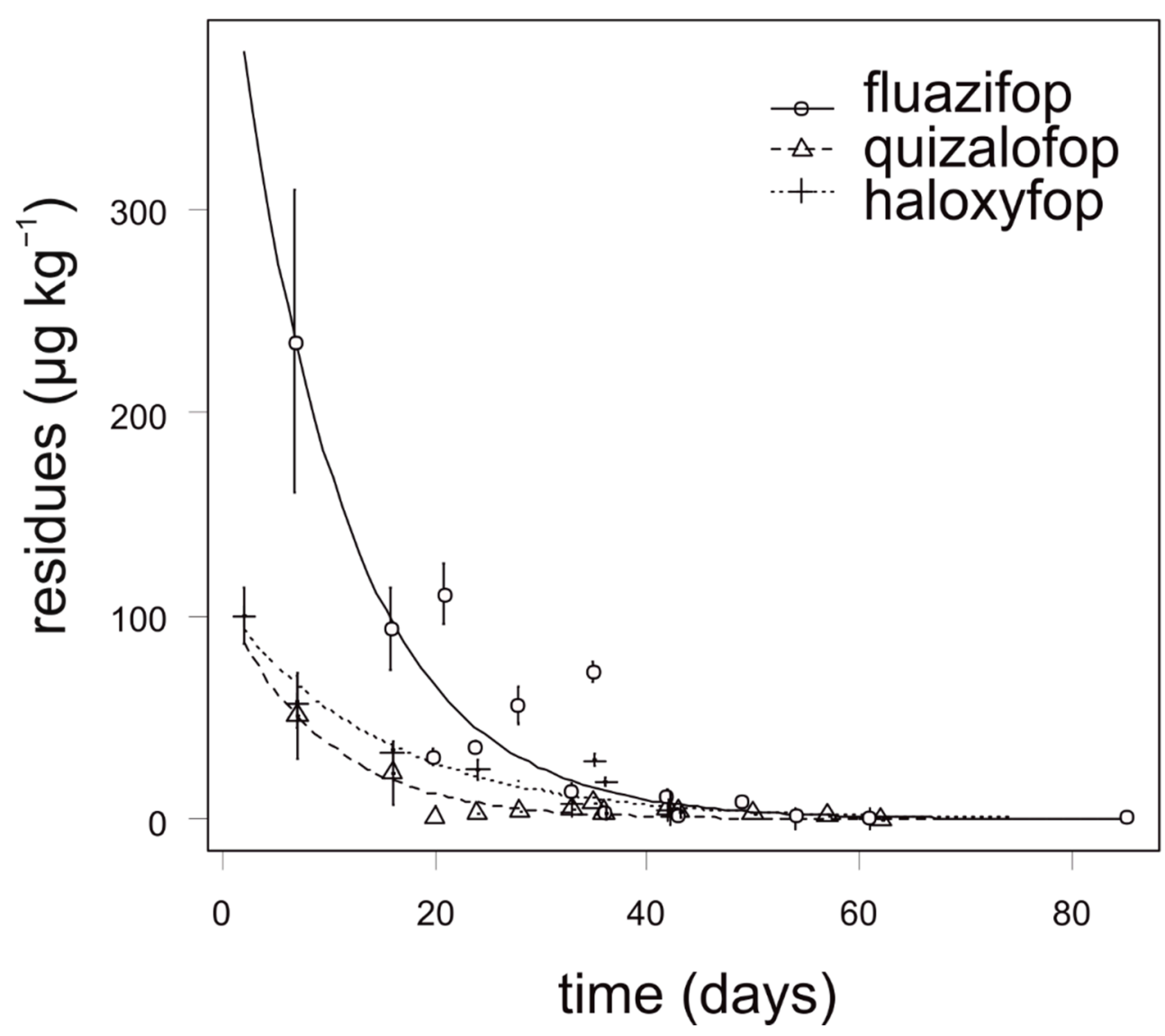

Figure 2. Degradation dynamics of fluazifop, quizalofop, and haloxyfop in onion. Mean values with error bars representing standard error of the mean.

\subsection{Lettuce}

During the first two weeks after application, fluazifop showed slower degradation in lettuce compared to quizalofop (Figure 3). The degradation dynamics of fluazifop were affected by the lettuce head size at the time of application. The highest concentration of fluazifop (350-550 $\mathrm{g} \mathrm{kg} \mathrm{k}^{-1}$ ) in lettuce was detected when herbicide was applied on almost ripened heads. In contrast, lettuce head size had no effect on quizalofop degradation. For fluazifop, the calculated $\mathrm{APHI}_{50}$ and $\mathrm{APHI}_{25}$ were equal and longer than $\mathrm{APHI}_{\mathrm{BF}}$ (60 days) due to a low MRL (20 $\mathrm{g} \mathrm{kg} \mathrm{k}^{-1}$ ). For quizalofop, the $\mathrm{APHI}_{50}$ was not relevant because it is shorter than PHI. APHI $\mathrm{BF}_{\mathrm{BF}}$ for quizalofop was 71 days (Table 7). Residues of propaquizafop and cycloxydim were not detected in any tested lettuce sample. Haloxyfop was not tested in lettuce. 


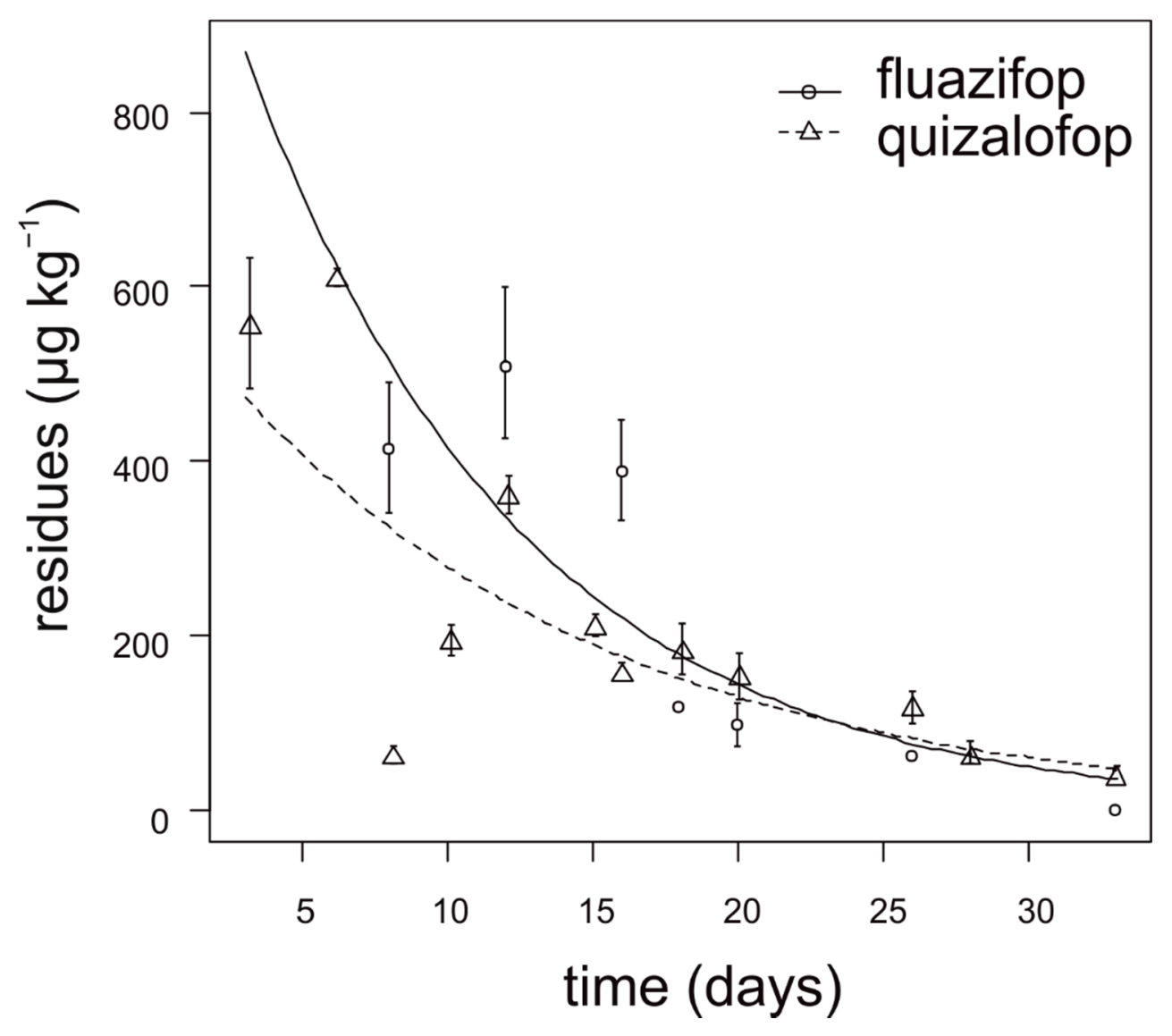

Figure 3. Degradation dynamics of fluazifop and quizalofop in lettuce. Mean values with error bars representing standard error of the mean.

\subsection{Cauliflower}

The degradation dynamics of fluazifop in cauliflower were significantly slower compared to quizalofop in all growing seasons (Figure 4). The concentration of fluazifop in all analyzed cauliflower samples was 18-220 times higher than MRL $\left(10 \mu \mathrm{g} \mathrm{kg}^{-1}\right)$. In contrast, the concentration of quizalofop in cauliflower did not exceed $100 \mu \mathrm{g} \mathrm{kg}^{-1}$ in any tested sample. For fluazifop, the calculated $\mathrm{APHI}_{50}$ and $\mathrm{APHI}_{25}$ were not relevant due to a low MRL; APHI was 105 days (Table 7). For quizalofop, 18 (50\% MRL), 33 (25\% MRL), and 68 days (for baby food) APHIs were calculated, while the PHI is prescribed as 70 days for brassica vegetables. No residues of propaquizafop and cycloxydim were found in any tested cauliflower sample. Haloxyfop was not tested for in cauliflower.

Days needed to reach the hypothetically set-up MRL values to 10, 20, 50, 100, 200, and $500 \mu \mathrm{g} \mathrm{kg}^{1}$, were calculated (Table 8). The aim here was to establish the baseline for a case in which authorities re-establish MRLs at new levels. Out of three active ingredients tested, the longest time was observed in fluazifop, regardless of the vegetable. In most cases, the model crops used in this study will obtain an MRL equal to $100 \mu \mathrm{g} \mathrm{kg}^{-1}$. 


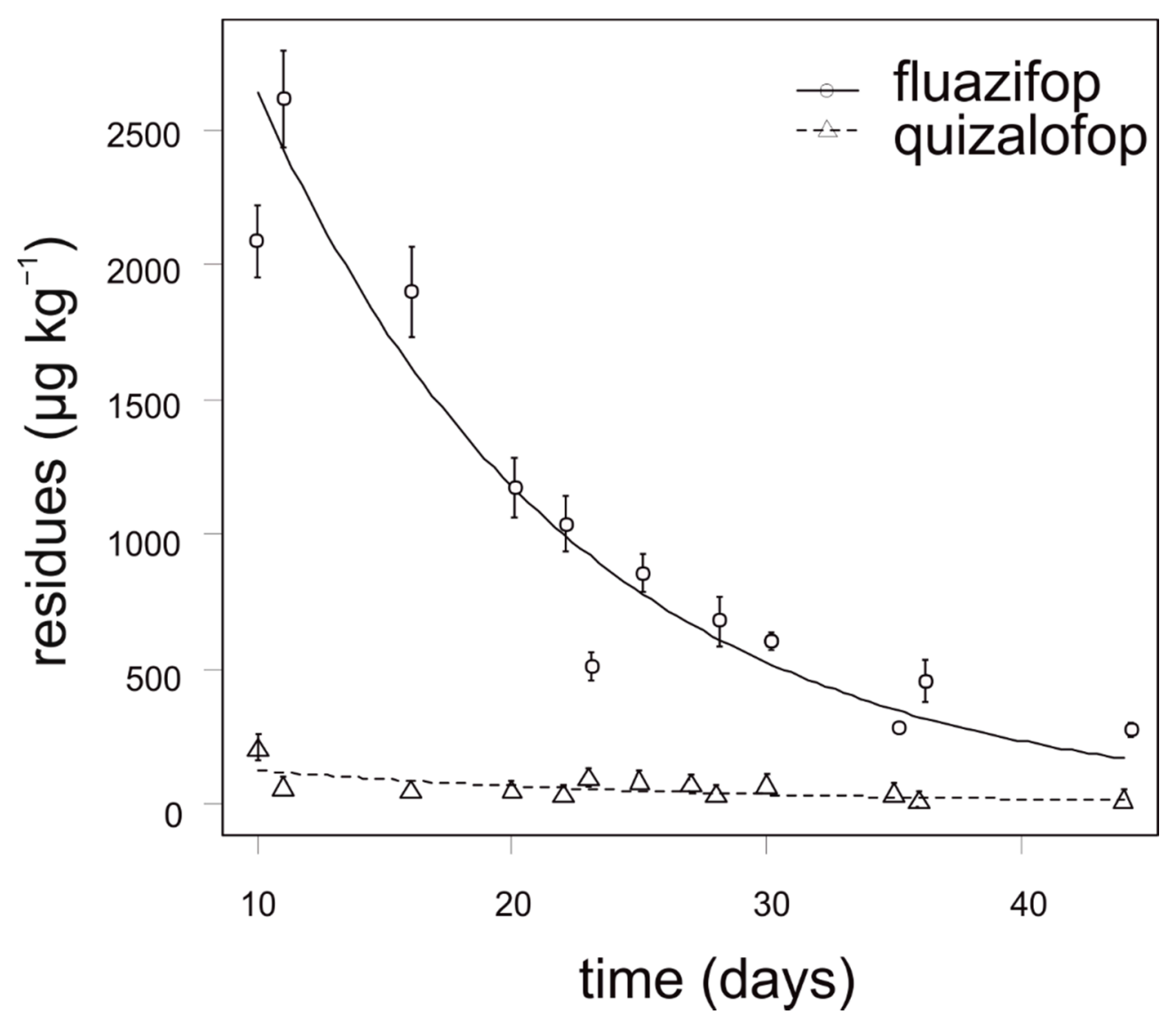

Figure 4. Degradation dynamics of fluazifop and quizalofop in cauliflower. Mean values with error bars representing standard error of the mean.

Table 8. Hypothetical pre-harvest interval for different MRL.

\begin{tabular}{|c|c|c|c|c|c|c|c|}
\hline Vegetable & $\begin{array}{c}\text { Active } \\
\text { Ingredient }\end{array}$ & $\begin{array}{c}\text { MRL } 10{ }^{1} \\
\text { (Days) }\end{array}$ & $\begin{array}{c}\text { MRL } 20^{2} \\
\text { (Days) }\end{array}$ & $\begin{array}{c}\text { MRL } 50^{3} \\
\text { (Days) }\end{array}$ & $\begin{array}{l}\text { MRL } 100^{4} \\
\text { (Days) }\end{array}$ & $\begin{array}{c}\text { MRL 200 } \\
\text { (Days) }\end{array}$ & $\begin{array}{c}\text { MRL 500 } \\
\text { (Days) }\end{array}$ \\
\hline \multirow{3}{*}{ carrot } & fluazifop & 110 & 70 & 57 & 52 & 26 & 9 \\
\hline & quizalofop & 55 & 45 & 15 & 12 & $x$ & $x$ \\
\hline & haloxyfop & 64 & 36 & 20 & 10 & $\mathrm{x}$ & $x$ \\
\hline \multirow{3}{*}{ onion } & fluazifop & 53 & 32 & 23 & 21 & 9 & $\mathrm{x}$ \\
\hline & quizalofop & 29 & 16 & 7 & 1 & $x$ & $x$ \\
\hline & haloxyfop & 47 & 26 & 9 & 1.26 & $x$ & $x$ \\
\hline \multirow{2}{*}{ lettuce } & fluazifop & 60 & 39 & 34 & 31 & 17 & 8 \\
\hline & quizalofop & 71 & 65 & 48 & 31 & 8 & $x$ \\
\hline \multirow{2}{*}{ cauliflower } & fluazifop & 105 & 83 & 75 & 67 & 42 & 31 \\
\hline & quizalofop & 68 & 45 & 21 & 18 & $x$ & $x$ \\
\hline
\end{tabular}

${ }^{1}$ maximum residue limit $10 \mu \mathrm{g} \mathrm{kg}^{-1} ;^{2} 20 \mu \mathrm{g} \mathrm{kg}^{-1} ;^{3} 50 \mu \mathrm{g} \mathrm{kg}^{-1} ;{ }^{4} 100 \mu \mathrm{g} \mathrm{kg}^{-1} ;{ }^{5} 200 \mu \mathrm{g} \mathrm{kg}^{-1} ;{ }^{6} 500 \mu \mathrm{g} \mathrm{kg}^{-1}$. In some cases, the calculated parameters reached value $<0$, this is not meaningful from practical point of view, so these are marked as $\mathrm{x}$.

\section{Discussion}

Of the tested leaf graminicides, fluazifop exhibited the slowest degradation dynamics in all tested vegetables. The highest amount $\left(2796 \mu \mathrm{g} \mathrm{kg}^{-1}\right)$ of fluazifop residues was detected in cauliflower 11 days after application. Similar degradation dynamics of fluazifop were recorded by Doohan et al. in strawberry [37]. In their study, residues of fluazifop ranged between 50 and $3240 \mu \mathrm{g} \mathrm{kg}^{-1}$ within 12-28 days after application. The half-life of fluazifop in vegetable leaf (lettuce and spinach) was relatively low and ranged from 
1.11 to 2.27 days [38]. Balinova and Lalova detected no residues of fluazifop in soybean seeds after harvest [39]; however, Sondhia detected a relatively high concentration of fluazifop both in straw $\left(472-702 \mu \mathrm{g} \mathrm{kg}^{-1}\right)$ and seeds $\left(297-312 \mu \mathrm{g} \mathrm{kg}^{-1}\right)$ of soybean after post-emergence application [40]. Risk of contamination of cauliflower and lettuce by fluazifop residue is relatively high due to the low MRL (10, resp. $20 \mu \mathrm{g} \mathrm{kg}^{-1}$ ) and slow dissipation. Moreover, the growing period of these vegetables is short (less than 60 days for lettuce and less than 90 days for cauliflower) and leaf graminicides are usually used $3-5$ weeks after planting crops. The MRL for fluazifop in onion and carrot is considerably higher (300, resp. $400 \mathrm{\mu g} \mathrm{kg}^{-1}$ ), therefore, fluazifop could be used in these vegetables, along with canopies, for low-residual production (up to 25\% MRL). Vegetables treated by fluazifop are not suitable for baby food due to the long APHI (53-110 days).

Concentration of quizalofop residues in all tested vegetable samples were below the MRL and did not exceed $400 \mu \mathrm{g} \mathrm{kg}^{-1}$ in lettuce and $100 \mu \mathrm{g} \mathrm{kg}^{-1}$ in carrot, onion, and cauliflower. Relatively low quizalofop residues in groundnut plants $\left(104 \mu^{\mathrm{g} \mathrm{kg}}{ }^{-1} 30\right.$ days after application) were detected by Poonia et al. [41]. In their study, quizalofop residues decreased below detection limit $\left(10 \mu \mathrm{g} \mathrm{kg}^{-1}\right) 60$ days after application. In blueberry fruit, no residues were detected two weeks after split application of quizalofop [42]. The halflife of quizalofop in potato leaves ranged from 0.04 to 13.1 days in study of Wang et al., and no residues were detected in leaves and tubers at harvest [7]. Similar results were presented by Mantzos et al., who detected quizalofop residues in stems and leaves of sunflower 18 days after application, but no residues in inflorescences and seeds at harvest time [11]. In addition, in our study, the degradation dynamics of quizalofop was slower in leaves of lettuce compared to roots of carrot, tubers of onion, or florets of cauliflower. This theory confirms the study of Sahoo et al., where they reported a very short half-life of quizalofop in onion ( 0.85 day) and no residue was detected at harvest time [43]. The risk of contamination of tested vegetables by quizalofop residues is low because of the fast degradation dynamics. The calculated APHI for 25\% MRL did not exceed PHI in any tested vegetable. Lettuce and cauliflower treated by quizalofop are not suitable for baby food due to long APHI (60, resp. 105 days), while onion and carrot could be treated by quizalofop (APHI for baby food 42, resp. 55 days).

A remarkably low quantity of residue was detected after application of haloxyfop. Only one sample of carrot (119 $\mathrm{g} \mathrm{kg} \mathrm{k}^{-1} 4$ days after application) exceeded the MRL. The degradation dynamics of haloxyfop in onion was fast and no onion samples contained more than $60 \mu \mathrm{g} \mathrm{kg}^{-1}$. However, concentration of haloxyfop residues in onion leaves could be significantly higher (100 and $800 \mu \mathrm{g} \mathrm{kg}{ }^{-1} 10$ days after application) [44]. Our suggested APHIs for $25 \%$ MRL did not exceed PHIs in onion and carrot. APHIs for baby food in these vegetables were relatively long (47 and 64 days, respectively), but possible.

No residues of propaquizafop were detected in any tested vegetable sample. Moreover, Duhan and Sing did not detect any residues of propaquizafop (detection limit $3 \mu \mathrm{g} \mathrm{kg}^{-1}$ ) in cotton seeds and lint at harvest time [45]. No other relevant studies about the degradation dynamics of propaquizafop in vegetables have been published yet, such as the degradation dynamics of cycloxydim. Both herbicides seem to be prospective for non-residual (baby food) vegetable production.

In comparison to other herbicides in vegetables, only residues of the soil active herbicide pendimethalin have frequently contaminated lettuce [31]. Contamination of cauliflower by herbicide clomazone, clopyralid, picloram, quinmerac, metazachlor, pyridate, dimethachlor, dimethenamid-P, S-metolachlor, napropamide, and pendimethalin was not detected in the study of Suk et al. [46]. This herbicide is usually applied shortly before or after planting/sowing and, therefore, a longer PHI could be achieved. Applications of leaf graminicides were carried out later, resulting in a PHI that was actually shorter. The main result of this study is that aryloxyphenoxy-propionate herbicides (except propaquizafop) could contaminate vegetables easily, especially vegetables with a short growing season. 


\section{Conclusions}

Aryloxyphenoxy-propionate herbicide (except propaquizafop) could contaminate vegetables easily, especially vegetables with a short growing season. Vegetables treated with fluazifop are not suitable for baby food. Lettuce and cauliflower treated by quizalofop are not suitable for baby food, but in onion and carrot, quizalofop could be used. Propaquizafop and cycloxydim are prospective herbicides for non-residual (baby food) vegetable production.

Author Contributions: Conceptualization, M.J.; methodology, M.J., K.H. and J.H.; software, K.H.; formal analysis, J.H.; investigation and resources, M.J.; writing—original draft preparation, M.J.; writing—review and editing, K.H.; visualization, K.H.; supervision, M.J.; project administration, M.J. All authors have read and agreed to the published version of the manuscript.

Funding: This research was funded by the Ministry of Agriculture of Czech Republic, grant number QK 21020238 and by the "National Programme of Sustainability I"-NPU I LO1601.

Institutional Review Board Statement: Non applicable.

Informed Consent Statement: Not applicable.

Acknowledgments: Authors very thank Theresa Piskackova from North Carolina State University for proofreading of the manuscript. Field experiments were carried out on Demonstrational and Experimental Centre of Faculty of Agrobiology, Food and Natural Resources, Czech University of Life Sciences Prague.

Conflicts of Interest: The authors declare no conflict of interest. The funders had no role in the design of the study; in the collection, analyses, or interpretation of data; in the writing of the manuscript, or in the decision to publish the results.

\section{References}

1. Abdulahi, A.E.; Modisa, O.; Molosiwa, O.; Mosarwe, L. Cynidon dactylon control in sunflower (Helianthus annuus) with postemergence graminicides in a semi-arid environment. Crop. Prot. 2001, 20, 411-414.

2. Gelmini, G.A.; Novo, M.; Mattos, J.B.S. Poaceae control by fenoxaprop-p-ethyl + clethodim in lettuce crop. Eccossistema 2000, $25,160-163$.

3. Vidrine, P.R.; Reynolds, D.B.; Blouin, D.C. Grasland control in soybean (Glycine max) with graminicides applied alone and with mixtures. Weed Technol. 1995, 9, 68-72. [CrossRef]

4. Kukorelli, G.; Reisinger, P.; Pinke, G. ACCase inhibitor herbicide-selectivity, weed resistance and fitness cost: A review. Int. J. Pest. Manag. 2013, 59, 165-173. [CrossRef]

5. Tichy, L.; Jursik, M.; Kolarova, M.; Hejnak, V.; Andr, J.; Martinkova, J. Sensitivity of sunflower cultivar PR63E82 to tribenuron and propaquizafop in different weather conditions. Plant. Soil Enviton. 2018, 64, 479-483.

6. Deer, J.F.; Monaco, T.J.; Sheets, T.J. Uptake and translocation of fluazifop by three annual grass. Weed Sci. 1985, 33, $612-617$. [CrossRef]

7. Wang, S.; Hou, Z.G.; Liang, S.; Lu, Z.B. Residue behavior and risk assessment of rimsulfuron and quizalofop-P-ethyl in potato under field condition. B Environ. Contam. Tox. 2020, 105, 602-606. [CrossRef]

8. Li, Z.Y.; Li, Q.L.; Cheng, F.N.; Zhang, W.S.; Wang, W.X.; Li, J.Y. Enantioselectivity in degradation and transformation of quizalofop-ethyl in soils. Chirality 2012, 24, 552-557. [CrossRef]

9. Kapsi, M.; Tsoutsi, C.; Paschalidou, A.; Albanis, T. Environmental monitoring and risk assessment of pesticide residues in surface waters of the Louros River (NW Greece). Sci. Total Environ. 2019, 650, 2188-2198. [CrossRef]

10. Correia, N.M.; Carbonari, C.A.; Velini, E.D. Detection of herbicide in water bodies of the Samambaia River sub-basin in the Federal District and eastern Goias. J. Environ. Sci. Health B 2020, 55, 574-582. [CrossRef]

11. Mantzos, N.; Karakitsou, A.; Nikolaki, S.; Leneti, E.; Konstantinou, I. Dissipitation and transport of quizalofop-p-ethyl herbicide in sunflower cultivation under field conditions. Environ. Sci. Pollut. Res. 2016, 23, 3481-3490. [CrossRef]

12. Saha, A.; Bhaduri, D.; Pipariya, A.; Jain, N.K. Influence of imazethapyr and quizalofop-p-ethyl application on microbial biomass and enzymatic activity in peanut grown soil. Environ. Sci. Pollut. Res. 2016, 23, 23758-23771. [CrossRef]

13. Horská, T.; Kocourek, F.; Stará, J.; Holý, K.; Mráz, P.; Krátký, F.; Kocourek, V.; Hajšlová, H. Evaluation of pesticide residue Dynamics in lettuce, onion, leak, carrot and parsley. Foods 2020, 9, 680. [CrossRef]

14. Jacobsen, R.E.; Fantke, P.; Trapp, S. Analysing half-lives for pesticide dissipitation in plants. SAR QSAR Environ. Res. 2015, 26, 325-342. [CrossRef] 
15. European Commission. Regulation (EC) no 396/2005 of the European Parliament and of the Council of 23 February 2005 a maximum residues levels of pesticides in or on foods and feed of plant and animal origin and amending Council Directive 91/414/EEC. This act has been changed. Latest consolidated version: 14/12/2019. Off. J. Eur Union 2005, 70, 1-16.

16. Kocourek, F.; Stará, J.; Holý, K.; Horská, T.; Kocourek, V.; Kováčová, J.; Kohoutková, J.; Suchanová, M.; Hajšlová, J. Evaluation of pesticide residue dynamics in Chinese cabbage, head cabbage and cauliflower. Food Addit. Contam Part A 2017, 34, 980-989. [CrossRef]

17. European Commission. Commission Directive 2006/125/EC of 5 December 2006 on processed cereal-based foods and baby foods for infants and young children. Off. J. Eur. Union 2006, 339, 16-35.

18. Panseri, S.; Nobile, M.; Arioli, F.; Biolatti, C.; Pavlovic, R.; Chieasa, L.M. Occurrence of perchlorate, chlorate and polar herbicides in different baby food commodities. Food Chem. 2020, 330, 127205. [CrossRef]

19. MacLoughlin, T.M.; Peluso, M.L.; Etchegoyen, M.A.; Alonso, L.L.; de Cstro, M.C.; Percudani, M.C.; Marino, D.J.G. Pesticide residues in fruits and vegetables of the argentine domestic market: Occurrence snd quality. Food Control 2018, 93, 129-138. [CrossRef]

20. Ramadan, M.F.A.; Abdel-Hamid, M.M.A.; Altorgoman, M.M.F.; AlGaramah, H.A.; Alawi, M.A.; Shati, A.A.; Shweeta, H.A.; Awwad, N.S. Evaluation of Pesticide residue in vegetables from the Asir region, Saudi Arabia. Molecules 2020, 25, 205. [CrossRef] [PubMed]

21. Bakirci, G.T.; Acay, D.B.Y.; Bakirci, F.; Otles, S. Pesticide residues in fruits and vegetables from the Aegean region, Turkey. Food Chem. 2014, 160, 379-392. [CrossRef]

22. Elgueta, S.; Velenzuela, M.; Fuetes, M.; Meza, P.; Manzur, J.P.; Liu, S.; Zhao, G.Q.; Correa, A. Pesticide residues and health risk assessment in tomatoes and lettuces from Farms of metropolitan region Chile. Molecules 2000, 25, 355. [CrossRef] [PubMed]

23. Skovgaard, M.; Encinas, S.R.; Jensen, O.C.; Andersen, J.H.; Condarco, G.; Jors, E. Pesticide residues in commercial lettuce, onion, and potato samples from Bolivia-A threat to public health? Environ. Health Insights 2017, 11, 1-8.

24. Santarelli, G.A.; Migliorati, G.; Pomilio, F.; Marfoglia, C.; Centorame, P.; D’Agostino, A.; D'Aurelio, R.; Scarpone, R.; Battistelli, N.; Di Simome, F.; et al. Assessment of pesticide residues and microbial contamination in raw leafy green vegetables marked in Italy. Food Control 2018, 85, 350-358. [CrossRef]

25. Chiarello, M.; Moura, S. Determination of pesticides in organic carrots by high-performance liquid chromatography/highresolution mass spectrometry. Anal. Lett. 2018, 51, 2561-2574. [CrossRef]

26. Singh, B.; Bhullar, M.S.; Walia, U.S.; Randhawa, S.K.; Phutela, R.P. Weed control in carrot (Daucas carota): Bio-efficacy and residues of pre-emergence herbicides. Indian J. Ecol. 2010, 37, 145-148.

27. Saritha, J.D.; Ramprakash, T.; Rao, P.C. Persistence of metribuzin in tomato growing soils and tomato fruits. Nat. Env. Poll. Tech. 2017, 16, 505-508.

28. Khan, S.U.; Belanger, A.; Hogue, E.J.; Hamilton, H.A.; Mathur, S.P. Residues of paraquat and linuron in an organic soil and their uptake by onions, lettuce and carrots. Can. J. Soil Sci. 1976, 56, 407-412. [CrossRef]

29. Sondhia, S. Harvest time residues of pendimethalin in tomato, cauliflower, and radish under field conditions. Toxicol. Environ. Chem. 2013, 95, 254-259. [CrossRef]

30. Esturk, O.; Yakar, Y.; Ayhan, Z. Pesticide residue analysis in parsley, lettuce and spinach by LC-MS/MS. J. Food Sci. Technol. 2014, 51, 458-466. [CrossRef]

31. Jursik, M.; Kovacova, J.; Kocarek, M.; Hamouzova, K.; Soukup, J. Effect of a non-woven fabric covering on the residual activity of pendimethalin in lettuce and soil. Pest. Manag. Sci. 2017, 73, 1024-1030. [CrossRef] [PubMed]

32. Jursik, M.; Kocarek, M.; Suchanova, M.; Kolarova, M.; Suk, J. Effect of irrigation and adjuvant on residual activity of pendimethalin and metazachlor in kohlrabi. Plant. Soil Environ. 2019, 65, 387-394. [CrossRef]

33. International Organization for Standardization. General Requirements for the Competence of Testing and Calibration Laboratories; ISO/IEC 17025:2005 (Revised by ISO/IEC 17025: 2017); BSI-ISO: London, UK, 2017.

34. EN 12393-2 Standard (Foods of plant origin-Multiresidue methods for the determination of pesticide residues by GC or LCMS/MS-Part 2: Methods for extraction and clean-up) and EN 12393-2 (Foods of plant origin-Multiresidue methods for the determination of pesticide residues by GC or LC-MS/MS-Part 3: Determination and confirmatory tests).

35. European Commission. Guidance Document on Analytical Quality Control. And Method Validation Procedures for Pesticide Residues and Analysis in Food and Feed; SANTE/12682/2019; DG SANTE: Bruxelles, Belgium, 2019.

36. Central Institute for Supervising and Testing in Agriculture. Available online: http://eagri.cz/public/web/en/ukzuz/portal (accessed on 22 December 2020).

37. Doohan, D.J.; Monaco, T.J.; Sheets, T.J.; Leidy, R.B. Residues and efficacy of fluazifop-buthyl in strawberries. Weed Res. 1986, 26, 89-98. [CrossRef]

38. Sufang, F.; Fengzu, Z.; Kailin, D.; Chuanshan, Y.; Shaowen, L.; Pengyue, Z.; Canping, P. Spinach or amaranth contains highest residues of metalaxyl, fluazifop-P-butyl, chlorpyrifos, and lambda-cyhalothrin on six leaf vegetables upon open field application. J. Agric. Food Chem. 2013, 61, 2039-2044.

39. Balinova, A.M.; Lalova, M.P. Translocation, metabolism and residues of fluazifop-butyl in soybean plants. Weed Res. 1992, 32, 143-147. [CrossRef]

40. Sondhia, S. Fluazifop-p-butyl residues in soybean crop and soil. Pestic. Res. J. 2007, 19, 248-250. 
41. Poonia, T.C.; Mathukia, R.K.; Karwasara, P.K. Residues of pendimethalin, oxyfluorfen, quizalofop-ethyl and imazethapyr in groundnut and their persistence in soil. J. Crop. Weed 2017, 13, 194-202.

42. Zou, R.; Wu, D.; Wu, L.; Li, Y.; Zhang, Z.; Liu, H. Residual dynamics of quizalofop-P-ethyl in blueberry fruit and soil. J. Jilin Agric. Uni. 2009, 31, 652-655.

43. Sahoo, S.K.; Mandal, K.; Singh, G.; Kumar, R.; Chahil, G.S.; Battu, R.S.; Singh, B. Residual behavior of quizalofop ethyl on onion (Allium cepa L.). Environ. Monit. Assess. 2013, 185, 1711-1718. [CrossRef]

44. Chakraborty, A.; Ghost, M.; Banerjee, H.; Bhattacharyya, A.; Roy, A. Pesticide behavior of haloxyfop-a new herbicide in/on onion. J. Crop. Weed 2005, 1, 41-44.

45. Duhang, A.; Sing, S. Terminal residues of propaquizafop in cotton seed, lint and soil. J. Cotton Res. Dev. 2018, 32, 133-138.

46. Suk, J.; Jursik, M.; Suchanova, M.; Schusterova, D.; Hamouzova, K. Dynamics of herbicide degradation in cauliflower. Plant. Soil Environ. 2018, 64, 551-556. [CrossRef] 